\title{
Endogenous Forest Development Paradigm: Challenging Current Forest Conservation Practices in Ghana
}

\author{
Thomas Agana, Millar Katherine Kaunza, David Millar \\ Faculty of Integrated Development Studies, University for Development Studies, Tamale, Ghana \\ Email: aganathom@yahoo.com
}

How to cite this paper: Agana, T., Kaunza, M.K. and Millar, D. (2018) Endogenous Forest Development Paradigm: Challenging Current Forest Conservation Practices in Ghana. Open Access Library Journal, 5: e4169.

https://doi.org/10.4236/oalib.1104169

Received: November 20, 2017

Accepted: March 9, 2018

Published: March 12, 2018

Copyright $\odot 2018$ by authors and Open Access Library Inc.

This work is licensed under the Creative Commons Attribution International License (CC BY 4.0).

http://creativecommons.org/licenses/by/4.0/ (c) (i) Open Access

\begin{abstract}
The centre of Ghana development is land that plays a vital role. This article focused mainly on the rapid land degradation and deforestation due to bush fires, poorly managed grazing, farming and agricultural conversion, current forest/woodland governance systems and major policy gaps that were identified. A combination of methods used included: Extensive study of secondary literature/reports/programmes/write-ups (from 1999-2004), key informant interview: a one-on-one interview with Government Officials, 7 responsible for forest management, Forestry, Commission and Traditional Institutions (men-10, women-5), elders-6, and functionaries- 4 living in the community, phased assertion. The study recommend Forest Management System needs to be evolved that includes the management and development of sacred groves, shrines, sacred bodies and natures, and totems; associated with indigenous agricultural practices and seeds, indigenous agro-ecological management practices, indigenous tree and vegetation management practices, indigenous livelihood developments and human activity systems which are both enhancing and militating against biodiversity conservation and development encourage and systematically develop traditionally protect areas/plants/animals (TPAs). Attention should be paid to conservation of: 1) sacred groves; 2) burial grounds and spiritual lands; 3) sacred water bodies and fauna; 4) totemic animals; 5) traditional cultural practices; 6) farming systems; 7) traditional crop varieties; 8) home gardens; 9) graze-lands and rest lands; 10) wild fruits supply systems.
\end{abstract}

\section{Subject Areas}

Biochemistry, Environmental Sciences

Keywords

Endogenous, Forest, Forest Development, Conservation, Forest Conservation, 
Savanna, Ecological

\section{Introduction: Forest in the Northern Savanna Zone}

The Northern Savanna lies within the Guinea Savanna and the Sudan Savanna ecological zones. As in many areas in Africa (for example Burkina Fasso) with similar ecological systems, savanna woodlands provide valuable environmental services and provide critical refuge for native biodiversity, and protection for soil and water resources against degradation. The northern savanna zone of Ghana supports about 20 percent of the national population and supplies about 70 percent of Ghana's total demand for firewood and charcoal estimated at about 16 million $\mathrm{m}^{3}$. The northern savanna zone also provides medicinal plants, roofing grasses, fencing poles, and fruits (for example, shea-nut, an increasingly important export commodity). Savanna bush meat, including various indigenous rodents, antelopes, reptiles and gastropods, is an important source of animal protein (providing about 12 percent of the rural communities' protein consumption) and revenue for local impoverished communities. The savanna woodlands also have beneficial effects on the local climate and constitute a natural barrier to the desiccating harmattan winds from the Sahara, helping to maintain a favorable microclimate for agricultural production, and protect major rivers and water bodies vital for the rest of Ghana.

The Sudan and Guinea savanna zones include the northern, drier, two-thirds of the Ghana, where the main economic activities are the production of annual crops (cereals, legumes, and root crops), cotton and livestock. At the beginning of the last century, woodlands were estimated to cover about 9.4 million hectares of the northern savanna zone, supplying mainly wood fuel and a small amount of building poles for local use. While the northern savannas are home to about one third of wildlife species in Ghana, annual bushfires affect 50 percent of the savannas, destroying species of flora and fauna and reducing biodiversity.

As in the high forest of Ghana, forest management in the northern savanna has been plagued with a number of constraints, which have limited rationalization of its potential and threatened its sustainable use over time. The forest and wildlife administrations are weak, with overlapping institutional responsibilities; there is insufficient involvement of communities in the management of the resources, coupled with negligible economic returns to the land and resource owners. There has been a lack of inter-agency coordination in planning and monitoring of natural resource use.

Unlike in neighboring Burkina Faso, unregulated exploitation of the ecosystem to satisfy socio-economic needs has resulted in some losses of biodiversity and severe resource depletion. The survival of indigenous land varieties of important food crops and an increasing number of medicinal plant species are be- 
ing threatened. Major causes are the expansion of agriculture into these regions, combined with over-grazing, bushfires, and inappropriate crop management. Reports indicate that in Burkina Faso there are full programmes addressing issues of conservation, enhancement and sustainable utilization of land, forest, sudano-savanna woodland and wildlife resources in active collaboration and consultation with rural communities and other rural institutions.

The savanna zones are also under tremendous pressure from growing human and livestock populations, agricultural expansion, inappropriate farming practices, woodland degradation, bush fires, and introduction of new crop varieties that are replacing indigenous varieties. Land degradation associated with loss of vegetation and inappropriate farming practices is a serious problem and is identified in the Ghana National Environmental Action Plan (NEAP) as one of the major environmental issues in Ghana.

Local communities and traditional authorities own all forest and savanna woodland reserves in Ghana and the government's role is to manage these resources in trust for the people. The key issues in natural resource management in Ghana are land and forest degradation and loss of flora and fauna biodiversity. These result from unsustainable harvesting levels in both the high forest (timber extraction) and savanna zones (poles/wood fuel and medicinal plants) and unsustainable land use practices especially crop farming and livestock grazing.

\section{The Conceptual Discussions}

Fulani (Fulbe) herdsmen are often accused of being primary agents of desertification in the Sudan-Sahelian zones of West Africa [1] (Bourliere, 1983; Scholes and Walker, 1993). As an increasing number of pastoralists migrate towards the southern savanna region, it is widely assumed that their pastoral activities will reduce forest cover through overgrazing and uncontrolled burning. There are alternative images of the environmental impact of savanna pastoralists by arguing that their herd and range management practices result, in the long term, in the expansion of tree cover [2] (Cline-Cole and Madge, 2000; Bassett and Boutrias, 2000). The contradictions are largely due to flawed models of land degradation in semi-arid areas to wetter savannas [3] (Fairhead and Leach, 1994; 1996). It is worth noting that Silvopasturism is an age old practice that has existed with indigenous African Communities for centuries. It is common practice to put herds of cattle into forest reserves to reduce biomass to reduce bushfires, open up reserves for better production of timber, and enhance silviculture [4] (Walters-Bayer et al., 1986).

According to [5] Bourfiere (1983) and also in [6] Gottfrid et al., (1994), the role of live stock raising in the expansion of woody plants of most savannas underscores the in appropriateness of forestry policies, notably those that seek total protection of reserves and parks from local land users. The notion that forests are degraded if not totally destroyed by livestock raising is so widespread that access to forest reserves is nearly always forbidden to livestock raisers. Only Ni- 
geria has instituted "Grazing Reserves" from which farmers are restricted. These are reserved spaces for livestock raisers and, at the sametime, are as where tree cutting is interdicted [7] (Clason and Sharrow, 2005); [8] (De-Gomez, 2006). The creation of these silvo-pastoral reserves was not the outcome of the application of ecological theory to the effects of livestock raising in savannas. Instead, it was' the dramatic reduction of grazing areas in the north of the country which forced authorities to offer some spatial compensation to livestock raisers. In the savannas of Burkina Faso, forest reserves were created in the form of linear bands that effectively divide rangelands. The boundaries of these reserves are drawn in such away that herders have difficulty moving from one grazing area to another. Herders complain of a severe policing of these forest zones which often results in fines and the seizure of cattle.

Trees and livestock raising are intimately related in West Africa. For example, in the Sahel region, shrubs are browsed not only by small ruminants but also by cattle. When trees attain too great a height, herders turn into wood cutters by climbing trees and cutting leafy branches to give to their animals waiting below. The contribution of trees to cattle diets is especially important during the dry season when animals are momentarily deprived of herbaceous pastures [9] (Griffis et al., 2001; Kolb, 2006). Ancient agro-pastoral civilisations ofWestAfrica depended onhighquality pasture grasses that were supplemented by treeforage. The symbol ofthis alliance between cattle and trees is the Acacia albida,acentral feature of regional agrarian civilisations [10] (Waters-Bayer and Taylor-Powell, 1986).

It is important to revisit the existing perceived contradiction between received wisdom (which is indigenous knowledge) and scientific views as regards the environmental impact of savanna pastoralism [11] (Stam, 2004). There is increasing evidence which suggests that, over the long term, herd and range management practices encourage an expansion in tree cover [12] (Shepperd, 2000; Miller et al., 2005).

\section{Methodology}

This research started with an extensive investigation into reports and documentation of the Savanna Resource Management Project (SRMP)—a World Bank Project. These documentations span (6 years, from 1999 till 2004) and it was obtained from Ministry of Land and Forestry (Savanna Resource Management Project Database)-ICT search Machine. The findings were supplemented with survey and stakeholder consultations [13] (Creswell, 2007; Creswell, 2009). The final outcomes were triangulated with Key Informant Interviews using Phased Assertion [14] (Yin, 2003). Open-ended questionnaires were used during the key informant interviews. The duration of the interview varied because of the open-ended questionnaires, but on average, 2 to 3 hours per respondent. The key informant interview was conducted after the reconnaissance and main research as in-depth studies.

A combination of methods used included: 
- Extensive study of secondary literature/reports/programmes/write-ups (from 1999-2004).

- Key Informant Interview. A one-on-one interview with Government Officials, 7 responsible for forest management, Forestry Commission and Traditional Institutions (men-10, women-5), elders-6, and functionaries-4 living in the community.

- Phased Assertion/Confrontational Dialogue as a way of triangulating and cross-validating the findings.

\section{Findings: Factors Influencing Savanna Forest Loss}

\section{1) Land Degradation and Deforestation}

About $30 \%$ to $40 \%$ of the total land area of Ghana experiences some form of land degradation. The main problems experienced are deforestation, overgrazing, water pollution, inadequate supplies of potable water, poaching, habitat destruction, and soil erosion (specifically: sheet erosion through surface runoff, rill erosion in impermanent and shifting micro-channels and gully erosion in permanent channels). In Ghana, land degradation and deforestation, are on-going processes in all parts of the country at various scales and intensities. It is estimated that between 1938 and 1981, the area of closed forest in Ghana was reduced by $64 \%$ from $47,000 \mathrm{~km}^{2}$ to $17,200 \mathrm{~km}^{2}$ and open woodland declined by $37 \%$ from $111,000 \mathrm{~km}^{2}$ to $69,800 \mathrm{~km}^{2}$ [15] (Schols and Walker, 1993).

The threat of desertification is however more prevalent in the Guinea and Sudan savanna zones of the Northern, Upper-East and Upper-West regions where the aridity index is 0.6 , around $80,000 \mathrm{~km}^{2}$ in Upper East and parts of Northern region are considered prone to desertification processes [16] (Environmental Protection Agency, 2002). This is from secondary information and is indexed between 0 and 1 . So, higher humidity is towards 1 and lower humidity (dryness) is towards 0 . The more dry it is means 0 and the less dry (wet) it is, means 1.

Current maps of human induced land degradation highlight particularly severe degradation in the far north-east of Ghana, in Upper East Region.

\section{2) Bush Fires}

The pervasive use of fire for land clearing in the farming systems of the desertification prone areas and uncontrolled late annual bush fires destroy forests, woodland and crops over extensive land areas. The litter which contributes organic matter to the soil is burnt and the land is laid bare and predisposed to water and wind erosion. Although the ash produced through burning of the vegetation increases nutrients such as calcium, magnesium, potassium and phosphorus the effect is transient. The nutrients are lost through leaching resulting in an increase in soil acidity and high levels of exchangeable aluminum. This limits the range of crops that can be grown. The annual bush fires have contributed to the slow regeneration of the vegetative cover of marginal lands and other un-cropped lands. The late bushfires have also contributed to the development of unpalata- 
ble forage which is not useful to the large numbers of livestock. Biodiversity is also lost and the whole habitat which supports wildlife and large numbers of ecologically interdependent species are destroyed.

\section{3) Poorly Managed Grazing}

Just as human numbers have increased over the years so has the population of livestock, especially cattle, sheep and goats. The Guinea and Sudan savanna zones carry most of Ghana's livestock population. Densities of cattle may range from 77 to 103 per $\mathrm{km}^{2}$ in the Bawku and Lawra districts respectively. The population increase has led to overgrazing of marginal lands. During the dry season, there is grazing pressure leaving most of the land bare except for a few withering brown perennial grass cover. The adverse consequences of overgrazing is a general deterioration in the quality and value of the grazing land, soil compaction due to trampling especially at water points, erosion by wind and water and a reduction of the productivity capacity of the range land.

The problem of overgrazing is compounded by cross-border pastoralism in which cattle herders from drier parts of the West African sub-region move southwards during the dry season, towards the more humid parts to graze their herds. These cross border movements do not only increase the livestock population of the savanna region tremendously, they worryingly, have led to sometimes violent clashes between crop farmers and pastoralists.

\section{4) Farming and Agricultural Conversion}

Agriculture in the desertification-prone zone is largely based on smallholder farms characterized by low input technologies and low output. Under these conditions, nutrient mining and exposure of the soil to erosion are common features of the farming system. Apart from farming, the demand for fuel wood and other wood products has led to degradation of woodland and forest over extensive areas. This is mainly through harvesting of poles for building purposes, fuel wood, charcoal production, bush fires, road construction, mining, sand and gravel winning.

\subsection{Current Forest/Woodland Governance Systems}

The woodland management systems currently promoted in Ghana include the following: [the following is a mix of areas with legal status like parks, conceptual things such as corridors, proposed special biodiversity conservation areas (birds/butterflies/monkeys), extremely and local household initiatives such as herb garderns. Other specific programmes include:

- Permanent protected forest (Forest Reserves).

- Wildlife Reserves (including National Parks, Resource Reserves, and Strict Nature reserves).

- Zoological gardens.

- Community Resource Management Areas (CREMAs).

- Globally Significant Biodiversity Areas (GSBAs).

- Imported Bird Areas (IBAs). 
- Biological Corridors (cross-border).

- Off-reserve Area Management.

- Development of Herbal Gardens.

- Sanctuaries and lagoon protection.

- River banks and Sea defense systems.

The protected area management system comprising the wildlife reserves and to a lesser extent forest reserves, represents the most organized biodiversity conservation method in the savanna zone. The maintenance of these systems fall mainly within the ambit of governmental institutions which are usually resource constrained and notoriously focused on the forest regions.

\subsection{Civil Society and Forest Management}

There are very few Non-governmental Organizations and Civil Societies involved in total Forest Management in northern Ghana. Each NGO/Civil Society identifies an aspect of forest and wildlife management and develops it as such. Hence here too there are no policies and concerted strategies for forest management. Some of these are:

- BURN;

- CECIK;

- TAAP;

- ACDEP;

- ZOFA;

- ZANSILARI;

- TUDRIDEP;

- HYPO SANCTURY WECHAIU (Community);

- HYPO SANCTURY TUMU (Community);

- JEFISI REPTILE SANCTURY (Community);

- SAMOA FOREST AND WILDLIFE RESERVE (Community).

The major per-occupation and motivation for the involvement of the NGOs is largely agricultural; issues of food security, agriculture and natural resource management issues. An investigation into their forest management strategies almost invariably ends with agricultural management strategies. Hence policy and strategy gaps are even more prominent with the NGO sector than for Government. There is the need to address this gap for the NGO sector.

\subsection{Major Policy Gaps Identified}

The general impression is that forests in Northern Ghana are enjoying conservation policies rather than policies to manage and develop them. Meanwhile these forest are being degraded by bushfires, mining, logging, charcoal burning, and uncontrolled herding. Hence there are no policy positions utilizing the reserves in an agreed upon management regime as is required by standard silvocultural practices (Table 1). This is a major handicap to the current forest management systems we have in Ghana. Additional gaps are as follows: 
Table 1. Some international conventions and policy frameworks for Ghana.

Conventions and Agreements relating to Forest Management in Ghana:

- Convention on African migratory locust: 1962.

- Treaty banning nuclear weapon tests in the atmosphere, in outer space and under water: 1963.

- International Convention for the conservation of Atlantic Tunas: 1966.

- African Convention on the conservation of nature and natural resources: 1968.

- Convention on wetlands of international importance, especially of waterfowl habitat: 1971.

- Convention concerning the protection of world cultural and natural heritage: 1972.

- Convention on international trade in endangered species of wild fauna and flora: 1973.

- Convention on the conservation of migratory species of wild animals: 1979.

- International tropical timber agreement: 1983.

- Montreal protocol on substances that deplete the ozone layer: 1987.

- Vienna convention for the protection of the ozone layer: 1989.

- Convention on biological diversity: 1992.

- Convention to combat drought and desertification: 1994

- Framework convention on climate change: 1992.

Adopted from: National Biodiversity strategy for Ghana (2002).

- From various policy and policy-type documents governing forest management systems the general observation is that there is very little reference made to northern savanna forest. Hence specific requirements of this region engender specific policy and strategic references. The lack of recognisition of the specific needs for savanna forest management and conservation is a general policy gap that needs to be addressed.

- As discussed in earlier chapters, it is common practice to put herds of cattle into forest reserves to reduce biomass; and in so doing, reduce bushfires, open up reserves for better production of timber, and enhance silviculture. A policy to support livestock - forest integration does not exist.

- Various indigenous forest conservations practices within the cultures of northern Ghana are not given the necessary policy attention and hence there are no strategies to enhance them as part of a holistic, integrated forest management programme.

- The nearness of the region to neighboring Burkina Faso, Ivory Coast, and Togo has its influences on forest management in the region. The cross-border issues are regularly referred to by communities living in this area. There are no forest management policies that deal with the cross-border influences.

- At the District level, the District Assemblies are mandated to fashion out by-laws to regulate various developmental activities in their communities. Forest management does not appear to be a priority hence the regulatory systems for this do not exist and so there are no resource allocations for it. There is no policy linkages between roles identified for traditional authority, community stakeholders and the District Assembly for forest management. There is the need to give policy backing to a link between such institutions and forest management. In doing this the involvement of local people should go beyond forest-fringing communities being part of forest and wildlife management as is the case now to a wider inclusion and integration of all stakeholders far and near.

- There are no policies for an incentive or reward systems for forest manage- 
ment. Marketing of forest products and by-products that could be a motivation for sustainable management is not foreseen by any northern savanna policy document. Issues of commercialization, export interests, and primarily the role of timber in the local and international economy are highlighted by policy. Value-addition and marketing linkages that could be a motivation for sustainable harvesting and use of plant and animal species as is done in some countries within the Sub-region is yet to receive policy attention for northern Ghana.

- With respect to wildlife, policy actions emphasize conservation over and above utilization. Also how to evolve a 'people-centered' wildlife management after realizing the role plaid by indigenous protection systems has not been sufficiently elaborated. The case has not also been made for a stronger linkage between wildlife and forest management for the savanna region. Though recognized in a couple of policy statements, it has not been highlighted as critical especially for northern Ghana.

- There is no policy position on savanna forest with respect to scenic beauty, tourism potential, scientific and research purposes, and teaching and learning as in educative purposes generally. Heritage preservation, conservation, and promotion should be part of such a policy.

- For the savanna region, the policy focus should be on the effect of small scale (legal and illegal) mining on forest cover, vegetation, and land and therefore biodiversity. These are the prime support systems for forest management and the potential effect of poorly managed mining on biodiversity and the environment. But policy does not address this critical area for northern Ghana.

- There is no policy effort addressing or committed to making a linkage between forest management and woodfuel utilization (even with respect to harvesting regimes and modalities). The need for energy, especially for rural communities, is on the increase. Such communities cannot afford alternative energy forms hence an over-dependence of woodfuels. Woodfuels also serve as a major source of income for the rural woman the harvesting of which depletes the forest.

- There are no policies and hence action strategies on Non-Timber/Non-Woody Forest Products (NTFPs) for the savanna regions of Ghana. The fact is that NTFPs have been grossly under-valued for northern Ghana. It appears they do not exist or they do not have any significance for Government. However these are of critical importance and have a huge potential for economic growth for especially the rual poor. There is the need for policy recognition for this and action strategies evolved to develop NTFPs [16] (Field survey, 2016).

\section{Conclusions}

A holistic and people-centered forest management system needs to be evolved that includes the management and development of sacred groves, shrines, sacred 
bodies and natures, and totems; associated with indigenous agricultural practices and seeds, indigenous agro-ecological management practices, indigenous tree and vegetation management practices, indigenous livelihood developments and human activity systems that are both enhancing and militating against biodiversity conservation and development.

Forest management strategies for the northern savanna region can be most effective where there is a paradigm shift of focus-from the current emphasis on Forest Conservation to Forest Management and Development (exclusions to responsible inclusions): Also from Forest Management per se to Endogenous Forest Management (EFM) - putting traditional authorities (even alien herdsmen), communities and local people as centre-stage and a focus on cultural diversities that impact on management and utilization of forests. Such a perspective gives due recognition for the several Traditional Protected Areas (TPA). The evidence shows that this perspective of forest management does not exist so far.

The "starting-from-within" concept (endogenous development-the proposed paradigm shift for forest management) will compel us to re-look at our forest policies and management strategies by:

- Starting with the indigenous management structures and systems that already exist in a community.

- Cultural roles and relevance as "enabling environments" for forest management.

- A people-centered choice of species types and combinations.

- Indigenous marketing systems, networks, and products.

- Culturally relevant forms of value-addition and systems for such.

- Profits and benefit-sharing systems that have elements of reciprocity arrangements, in-kind, individually, family level, and larger collectivities.

- Seriously considering the integration of herdsmen into our forest reserves with a strict silvocultural practice regime.

\section{Recommendation}

Integration of Fulaini/ Fulbe herdsmen, who take care of both their cattle and cattle owned by Ghanaians, into our forest reserves under the following terms:

- Based on agreed upon management practices in silvoculture that with both protect and enhance the integrity of the reserves.

- Reduce biomass and hence reduce intensity of destructive bushfires.

- Prune and provide ideal tree population for large timber production with pruned materials for livestock feeding.

- Rejuvenate degraded areas in the reserves and also broadcast leguminous fodder species for the supplementary feeding of livestock (Styllozanthis).

- Practice health and husbandry of both forests and livestock.

- Pay agreed taxes in-kind or in-cash to the District Assemblies abutting the forest reserves as internally generated revenues.

For Endogenous Forest Management strategies, it requires that due recogni- 
tion be given to traditional conservation practices that have persisted over several hundreds of years (including herd management). Even though earlier population densities were low, natural resources appeared "limitless" and hunting and farming practices did little damage to the environment, traditional laws and practices on conservation were still in-place. These laws and practices, some of which persist to date, tended to protect the ecology in three main ways:

1) By protecting specific ecosystems and land types.

2) By protecting particular plant/animal species.

3) By regulating the exploitation of plant and animal resources (Taboo days, close seasons).

A few of the possible activities that could be promoted form and Endogenous Forest Management perspective include the following:

- Promotion of alternative resource management systems (the role of indigenous knowledge, indigenous institutions, and indigenous management systems).

- Forest management and tourism (also cultural tourism, festivals and social occasion and biodiversity).

- Forest management and medicinal plants and animals (linking this to local and external markets).

- Forest management and alternative livelihood/income substitution activities (NTFPs and NWFP).

- An integrated programme of bio-cultural diversity, agriculture, agro-forestry, forest management, water body management, soil fertility improvement, fishery, wildlife.

- Indigenous forms of species preservation, germplasm preservation, protection of "indigenous hot spots" and endangered species.

To encourage and systematically develop traditionally protect areas/plants/animals (TPAs), attention should be paid to conservation of:

- Sacred groves.

- Burial grounds and spiritual lands.

- Sacred water bodies and fauna.

- Totemic animals.

- Traditional cultural practices.

- Farming systems.

- Traditional crop varieties.

- Home gardens.

- Graze-lands and rest lands.

- Wild fruits supply systems.

\section{References}

[1] Bourfiere, F. (Ed.) (1983) Tropical Savannas. Ecosystems of the World, No. 13.

[2] Clason, T. and Sharrow, S. (2005) Silvopastoral Practices. In: Garrett, H.E., Rietbeld, W.J. and Fisher, R.F., Eds., North American Agro-Forestry: An Integrated Science and Practice, American Society of Agronomy, Inc., Madison, Wisconsin, 119-147.

[3] Creswell, J.W. (2007) Qualitative Inquiry and Research Design: Choosing among 
Five Approaches. $3^{\text {rd }}$ Edition, Sage, Thousand Oaks CA.

[4] Creswell, J.W. (2009) Research Design. 3rd Edition, SAGE Publications, Inc., Thousand Oaks.

[5] De-Gomez, T. (2006) Guidelines for Thinning Ponderosa Pine for Improved Forest Health and Fire Prevention. University of Arizona Cooperative Extension, Publication AZ1397.

[6] Fairhead, J. and Leach, M. (1994) Contested Forests: Modern Conservation and Historical land Use in Guinea's Ziama Reserve. African Affairs, 93, 481-512. https://doi.org/10.1093/oxfordjournals.afraf.a098756

[7] Fairhead, J. and Leach, M. (1996) Enriching the Landscape: Social History and the Management of Transition Ecology in the Forest-Sanana Mosaic of the Republic of Guinea. Africa, 66, 14-36. https://doi.org/10.2307/1161509

[8] Gottfrid, G.J. and Severson, K.E. (1994) Managing Pinyon-Juniper Woodlands. Rangelands, 16, 234-236.

[9] Griffis, K.L., Crawford, J.A., Wagner, M.R. and Moir, W. (2001) Understory Diversity in Ponderosa Pine Forest Stands of Various Management Histories in Northern Arizona. Forest Ecology and Management, 146, 239-245. https://doi.org/10.1016/S0378-1127(00)00461-8

[10] Kolb, P.F. (2006) Forestland Grazing: Understory Forage Management.

[11] Miller, R.F., Bates, J.D., Svejcar, T.J., Pierson, F.B. and Eddleman, L.E. (2005) Biology, Ecology, and Management of Western Juniper. Oregon State University Agricultural Experiment Station, Technical Bulletin 152.

[12] Shepperd, W.D. (2000) Manipulations to Regenerate Aspen Ecosystems. Symposium Proceedings on Sustaining Aspen in Western Landscapes, 13-15 June 2000, RMRS-P-18, Grand Junction, Colorado, 355-366.

[13] Stam, B.R. (2004) Quantifying Losses of Understory Forage in Aspen Stands on the Dixie and Fishlake National Forests. M.S. Thesis, Utah State University, Logan, Utah.

[14] Schols, R.J. and Walker, B.H. (1993) An African Savanna: Synthesis of the Nylsvley Study. Cambridge University Press, Cambridge. https://doi.org/10.1017/CBO9780511565472

[15] Waters-Bayer, A. and Taylor-Powell, E. (1986) Settlement and Land Use by Fulani Pastoralists in Case Study Areas', in ILCA. Livestock Systems Research in Nigeria's Sub-Humid Zone. ILCA, Addis Ababa, 213H.26.

[16] Yin, R.K. (2003) Case Study Research. 3rd Edition, Sage, Thousand Oaks, CA. 